Proc. Estonian Acad. Sci. Geol., 1999, 48, 2, 99-109

\title{
SIMULATION OF THE POST-GLACIAL BALTIC SEA SHORELINES ON HIIUMAA ISLAND, WEST ESTONIAN ARCHIPELAGO
}

\author{
Tiit $\mathrm{HANG}^{\mathrm{a}, \mathrm{b}}$ and Toomas KOKOVKIN ${ }^{\mathrm{c}}$
}

a Department of Quaternary Research, Stockholm University, 10691 Stockholm, Sweden
b Institute of Geography, University of Tartu, Vanemuise 46, 51014 Tartu, Estonia; hang@gi.ee
${ }^{\text {c }}$ Research Centre Arhipelaag, Vabrikuväljak 1, 92411 Kärdla, Estonia; toomas@ bka.hiiumaa.ee

Received 21 July 1998, in revised form 22 February 1999

\begin{abstract}
A GIS-based simulation of the emergence of Hiiumaa Island in post-glacial time is provided on the basis of shoreline (geomorphological) data. Taking uneven crustal movements into account, simulated contours of the island for separate time slices of the Ancylus Lake and Litorina Sea transgressive periods and the Ancylus Lake regressive period in the evolution of the Baltic Sea are compared with the previous manually constructed schemes. The method yielded promising results and is recommended for use in further shore displacement investigations in Estonia.
\end{abstract}

Key words: Baltic Sea, Ancylus Lake, Litorina Sea, shore displacement, land uplift, GIS, Hiiumaa Island, Kõpu Peninsula.

\section{INTRODUCTION}

The uplift of the Earth's crust is easily recognizable in the coastal areas of Estonia. This well-known phenomenon, the origin of which has been a subject of lively discussions among Scandinavian scientists, was first described and explained by De Geer (1888). He mapped the concentric isobases of the uplift with the centre in the coastal area of the Gulf of Bothnia. Comparing the isobases with the maximum extension and recession of the Weichselian glacier, De Geer reached the conclusion that the uplift was a function of the glacial loading glacial isostasy.

With the expansion of the knowledge during the 20th century it became clear that the late- and post-glacial movements, which rapidly changed in space and time, were of complicated character. For the purposes of this paper, as land uplift we consider a total effect of (1) eustatic rise of ocean level (mainly due to the melting of the big continental ice cap) and (2) isostatic movements of the Earth's crust. 
In Estonia, the data concerning land uplift has mainly been obtained through the study of the raised coastal formations of the Baltic Sea. Geomorphological, biostratigraphical, and ${ }^{14} \mathrm{C}$ methods have been used in dating ancient shorelines. The results show that Estonia's territory has been uplifting during late- and postglacial times. The unequal land uplift has affected different areas in different ways. Thus, the coastal formations in northern Estonia are located higher above sea level than the coastal formations of the same age in southern Estonia. The altitude of the highest, Baltic Ice Lake shoreline ranges from $70 \mathrm{~m}$ in northern Estonia to only $35 \mathrm{~m}$ in southwestern Estonia, evidencing that at that time a great part of Estonia's territory was covered by water. In the existence of the Baltic Ice Lake, the Earth's crust rose at least $65 \mathrm{~m}$ in northwestern Estonia. During the entire subsequent period, however, it rose only $50 \mathrm{~m}$. The average annual uplift for the same periods in the same area was 26.5 and $4.2 \mathrm{~mm} / \mathrm{yr}$, respectively (Kessel \& Miidel, 1973).

The shift of the Fennoscandian uplift centre during late- and post-glacial times caused changes not only in the rate of the uplift, but also in the direction of tilting. At the time of the existence of the Baltic Ice Lake, the direction of tilting was $335^{\circ}$, during the post-glacial Ancylus Lake and Litorina Sea stages of the Baltic Sea about $326^{\circ}$, and at present it is $310^{\circ}$ (Kessel \& Miidel, 1973).

The effect the faster uprising in a northwesterly direction exerted was also revealed by the investigation of relatively small territories with simple topography, like Hiiumaa Island (Dagö). Several shoreline maps, showing the shore displacement and the emergence of the island, have been issued since the pioneer publication by Kents (Kents, 1939; Sepp, 1974; Kessel \& Raukas, 1979; Ratas \& Raukas, 1995). Thus, in the northern and northwestern parts of the island the shoreline of the transgressive Ancylus Lake is traceable at an altitude of $45 \mathrm{~m}$, while in the southeast it is at an altitude of $35 \mathrm{~m}$. The altitude of the transgressive Litorina Sea shoreline in these areas is 27 and $20 \mathrm{~m}$, respectively.

Environmental methods are being increasingly applied in social sciences, including history and archaeology, for both inventory and dating purposes. An important task of natural sciences is to reconstruct the shore displacement and to determine the altitude of shorelines for certain historical periods. At the same time, the above-mentioned differences in land uplift make palaeogeographical reconstructions in the area very complicated. That is why the investigations carried out so far have mostly ignored the variations in the intensity of land uplift. As a heritage from the Soviet period, former palaeogeographical schemes are often deformed and lack geographical coordinates, which makes them very difficult to compare with the recent topographical maps. Thus there is an acute need for an objective tool, which would enable one to test current views on the shore displacement in Estonia, on the one hand, and to carry out detailed investigations, on the other hand. The various computer software available provide such possibilities. In the following, the results of an attempt to simulate the best preserved Ancylus Lake (c. $9200 \mathrm{yr}$ BP) and Litorina Sea (in this work 
the first Litorina transgressive period $c .7000 \mathrm{yr} \mathrm{BP}$ is considered) transgressive shorelines on Hiiumaa Island (western Estonia) on the basis of a recent digital terrain model, geomorphological and biostratigraphical data will be presented. Also, the shoreline of the regressive period of the Ancylus Lake is discussed.

\section{METHODS}

The basic idea behind the method used was subtracting altitudes of land uplift from the digital elevation model (DEM) of the island to obtain the DEMs for several periods and separate time slices in the past. Extensive computerized calculations were needed because the subtracted surfaces are not parallel to the recent sea surface due to above-described uneven tectonic movements.

To obtain the DEM of the recent topography, the basic digital map of Estonia with 5-m steps between isolines was used (Fig. 1). The DEM was created by means of the INTERCON module of the GIS package IDRISI. Subsequent calculations and the layout were prepared with the SURFER software.
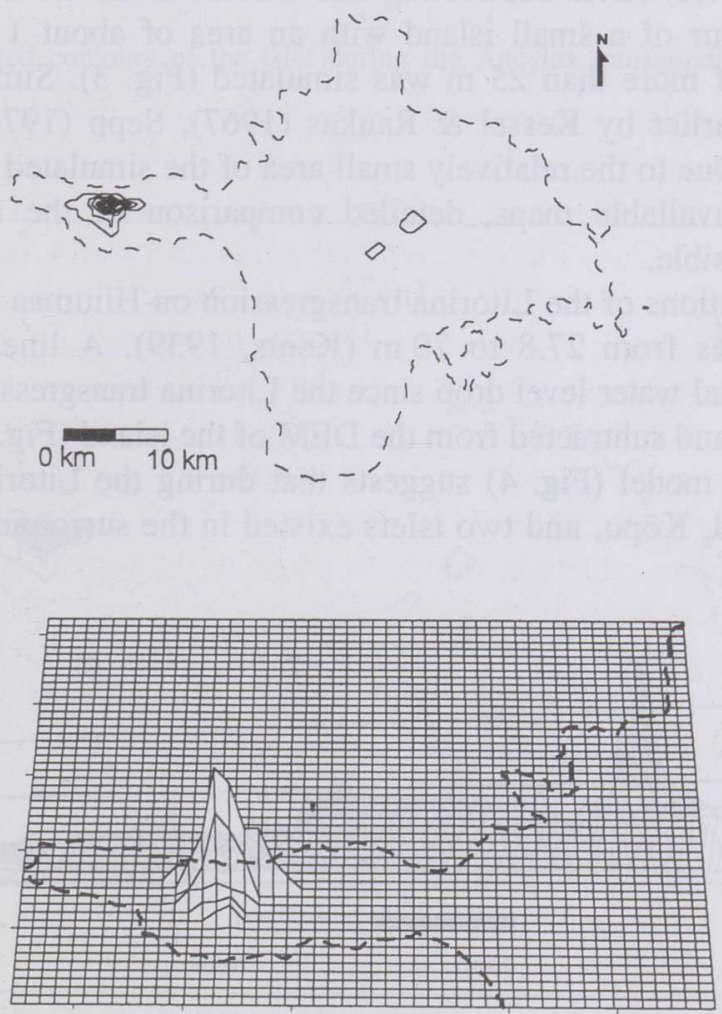

Fig. 1. Location of the investigated area (top) and recent terrain model (bottom) of the Kõpu Peninsula (Hiiumaa Island). Isolines after $5 \mathrm{~m}$. 


\section{RESULTS AND DISCUSSION}

As a result of the glacioisostatic uplift during the late- and post-glacial periods, Hiiumaa Island has been continuously rising. The development of the island began soon after the retreat of the Weichselian ice sheet, when the highest part ( $68 \mathrm{~m}$ a.s.1.) of the Kõpu Peninsula emerged from the water. The highest shorelines of that period lie at altitudes of 60.8, 54.8, and $53.4 \mathrm{~m}$ (Kents, 1939) and are related to the Baltic Ice Lake (Raukas \& Ratas, 1996) or to the Yoldia Sea (Kessel \& Raukas, 1967).

The Ancylus transgression in Estonia culminated approximately 92009000 yr BP (Haila \& Raukas, 1992). Traces of this transgression in the form of coastal scarps in the Kõpu area have been found at $45-44 \mathrm{~m}$ a.s.l. (Kents, 1939). Hence, the total relative drop of water level since the Ancylus transgression has been about $45 \mathrm{~m}$ in western Hiiumaa. Interpolation of the shoreline data of the same transgression from mainland Estonia to Hiiumaa Island showed that during the same period the water level in the southeastern part of the island dropped about $35 \mathrm{~m}$. According to this data, a plane linear surface inclined from NW to SE was constructed. After subtracting this surface from the DEM of Hiiumaa (Fig. 2), a contour of a small island with an area of about $1 \mathrm{~km}^{2}$ and with a relative height of more than $25 \mathrm{~m}$ was simulated (Fig. 3). Similar results have been obtained earlier by Kessel \& Raukas (1967), Sepp (1974), and Ratas \& Raukas (1995). Due to the relatively small area of the simulated Kõpu island and small scale of available maps, detailed comparison of the above-mentioned results is not possible.

Coastal formations of the Litorina transgression on Hiiumaa Island have been found at altitudes from 27.8 to $20 \mathrm{~m}$ (Kents, 1939). A linear plain surface simulating the total water level drop since the Litorina transgression (7000 yr BP) was constructed and subtracted from the DEM of the island (Fig. 2).

The resulting model (Fig. 4) suggests that during the Litorina transgression one bigger island, Kõpu, and two islets existed in the surroundings of Kapasto

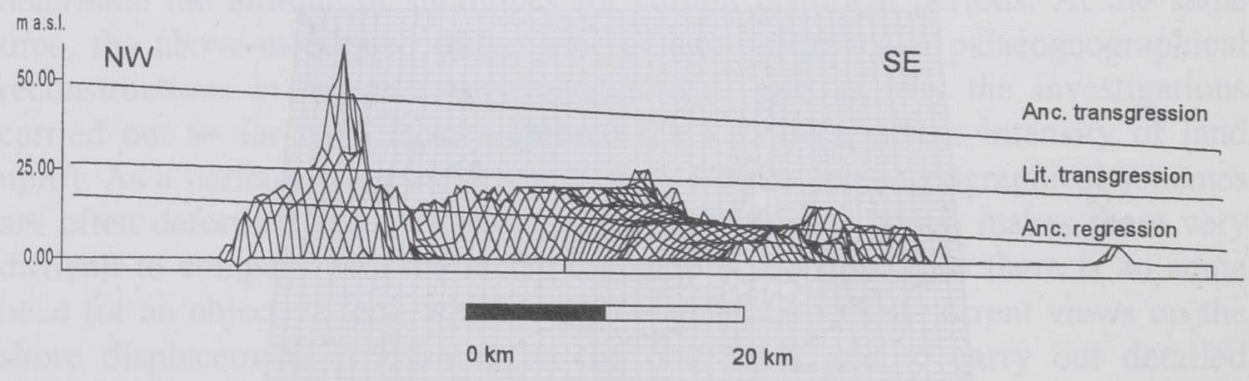

Fig. 2. Cross-profile of Hiiumaa Island along the NW-SE $\left(326^{\circ}\right)$ oriented line. Water level of the Baltic during the Ancylus and Litorina transgressions and Ancylus regression is shown with separate lines. 


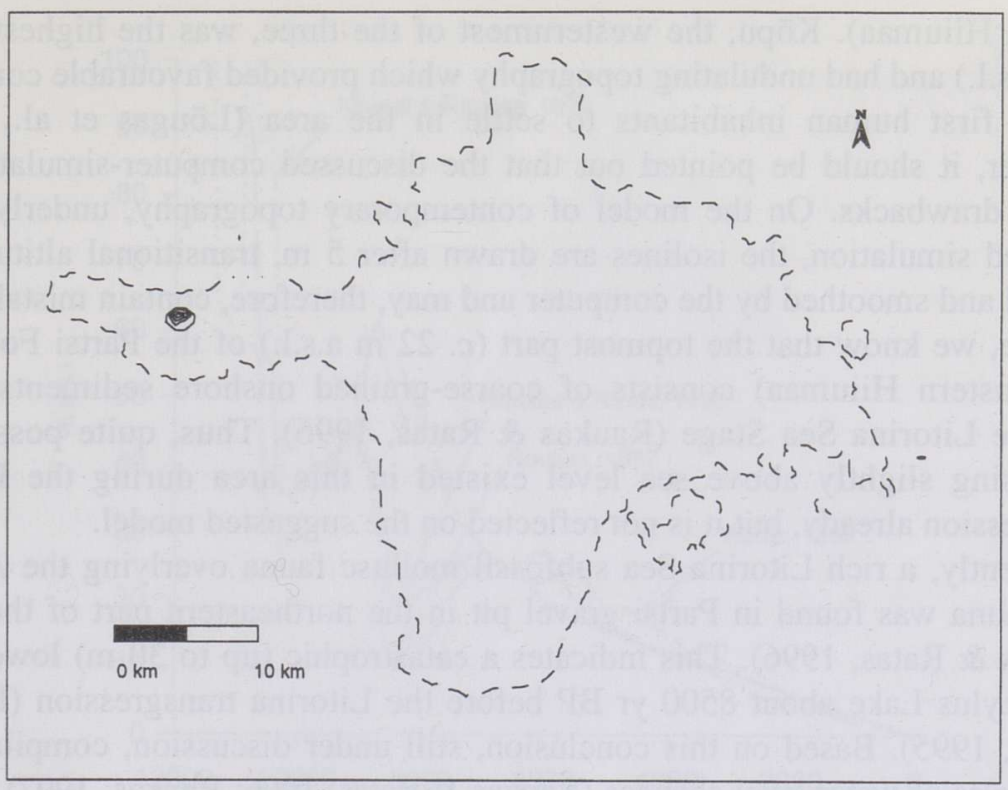

Fig. 3. The simulated contours of the islet during the Ancylus transgression (c. 9200 yr BP). Isolines after $5 \mathrm{~m}$.

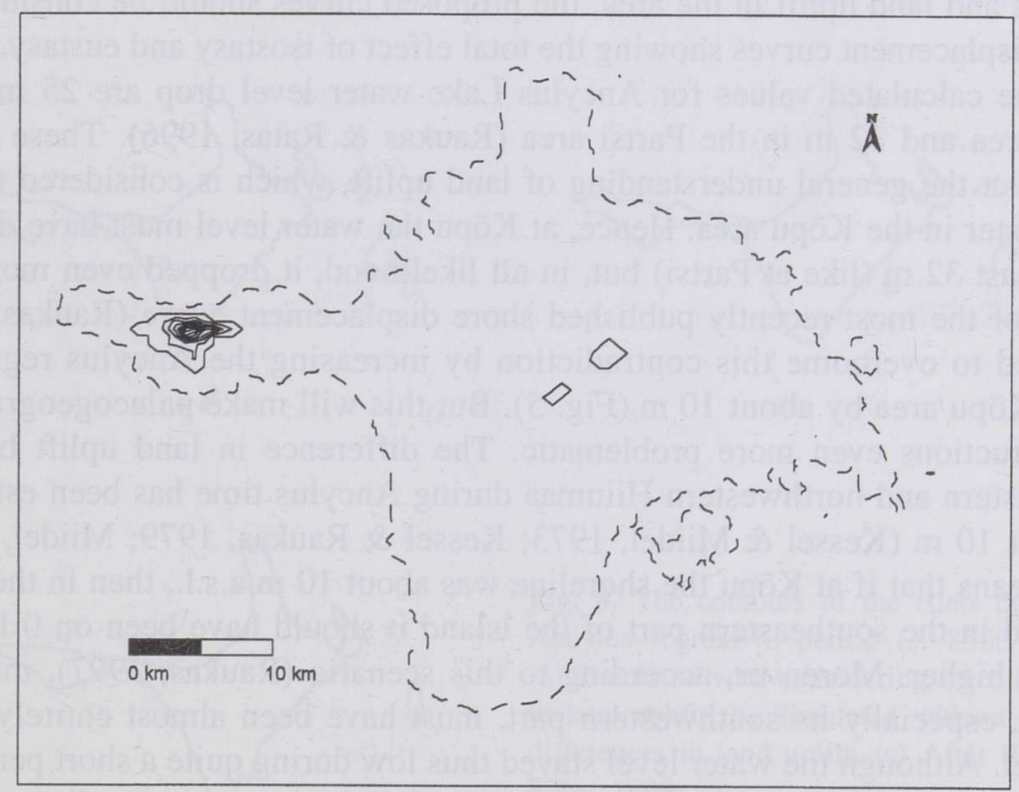

Fig. 4. The simulated contours of the islets during the Litorina transgression (c. $7000 \mathrm{yr}$ BP). Isolines after $5 \mathrm{~m}$. 
(central Hiiumaa). Kõpu, the westernmost of the three, was the highest (up to $40 \mathrm{~m}$ a.s.1.) and had undulating topography which provided favourable conditions for the first human inhabitants to settle in the area (Lõugas et al., 1996). However, it should be pointed out that the discussed computer-simulation has several drawbacks. On the model of contemporary topography, underlying the proposed simulation, the isolines are drawn after $5 \mathrm{~m}$, transitional altitudes are counted and smoothed by the computer and may, therefore, contain mistakes. For instance, we know that the topmost part (c. $22 \mathrm{~m}$ a.s.l.) of the Partsi Formation (northeastern Hiiumaa) consists of coarse-grained onshore sediments dating from the Litorina Sea Stage (Raukas \& Ratas, 1996). Thus, quite possibly an islet rising slightly above sea level existed in this area during the Litorina transgression already, but it is not reflected on the suggested model.

Recently, a rich Litorina Sea subfossil mollusc fauna overlying the Ancylus Lake fauna was found in Partsi gravel pit in the northeastern part of the island (Raukas \& Ratas, 1996). This indicates a catastrophic (up to $30 \mathrm{~m}$ ) lowering of the Ancylus Lake about 8500 yr BP before the Litorina transgression (Ratas \& Raukas, 1995). Based on this conclusion, still under discussion, compilation of new curves of water level changes (Raukas \& Ratas, 1996; Raukas, 1997) (Fig. 5) and simulation of the contours of Hiiumaa Island at that time has been suggested (Raukas \& Ratas, 1996) (Fig. 6c). Unfortunately, the authors of the new curves of water level changes (Raukas \& Ratas, 1996; Raukas, 1997) (Fig. 5) have not presented the basic background data. According to the general idea of water level changes and land uplift in the area, the proposed curves should be considered as shore displacement curves showing the total effect of isostasy and eustasy. In that case, the calculated values for Ancylus Lake water level drop are $25 \mathrm{~m}$ in the Kõpu area and $32 \mathrm{~m}$ in the Partsi area (Raukas \& Ratas, 1996). These figures contradict the general understanding of land uplift, which is considered to have been faster in the Kõpu area. Hence, at Kõpu the water level must have dropped by at least $32 \mathrm{~m}$ (like at Partsi) but, in all likelihood, it dropped even more. The author of the most recently published shore displacement curve (Raukas, 1997) has tried to overcome this contradiction by increasing the Ancylus regression in the Kõpu area by about $10 \mathrm{~m}$ (Fig. 5). But this will make palaeogeographical reconstructions even more problematic. The difference in land uplift between southeastern and northwestern Hiiumaa during Ancylus time has been estimated at about 10 m (Kessel \& Miidel, 1973; Kessel \& Raukas, 1979; Miidel, 1995). This means that if at Kõpu the shoreline was about $10 \mathrm{~m}$ a.s.l., then in the Partsi area and in the southeastern part of the island it should have been on 0 level or slightly higher. Moreover, according to this scenario (Raukas, 1997), mainland Estonia, especially its southwestern part, must have been almost entirely above sea level. Although the water level stayed thus low during quite a short period, its traces should have preserved in the sediments, but these were never discovered in the area. Therefore, the shore displacement curve presented by Raukas (1997) should be taken as hypothetical. 


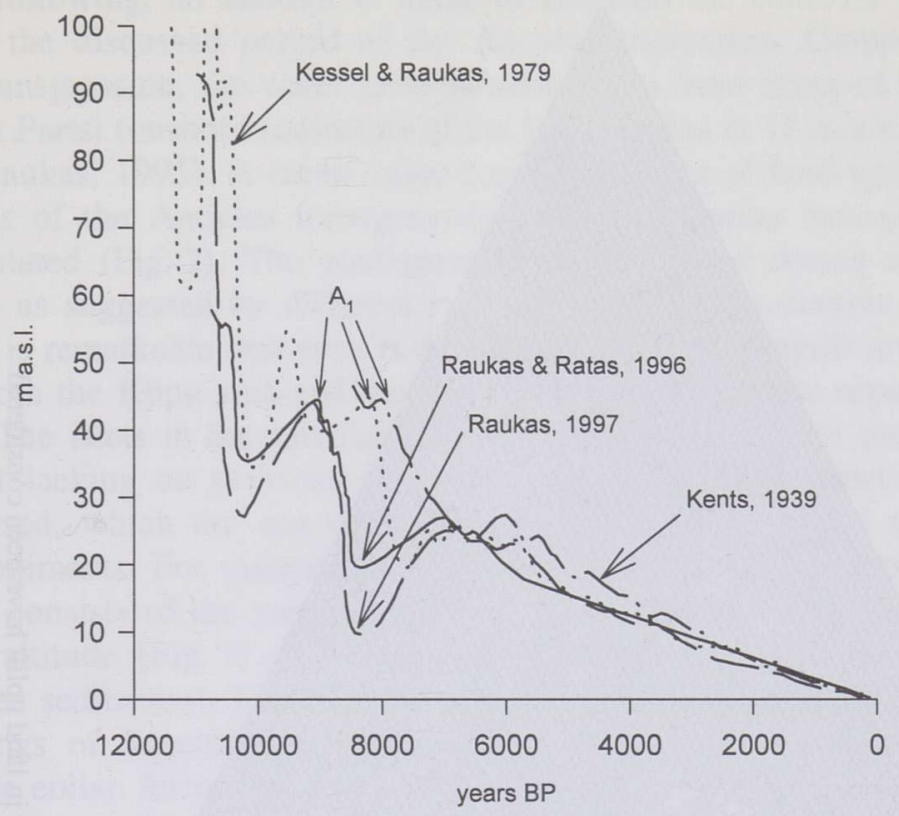

Fig. 5. Shore displacement curves obtained for the Kõpu Peninsula, Hiiumaa Island. $A_{1}$, water level during the Ancylus transgression according to different authors.

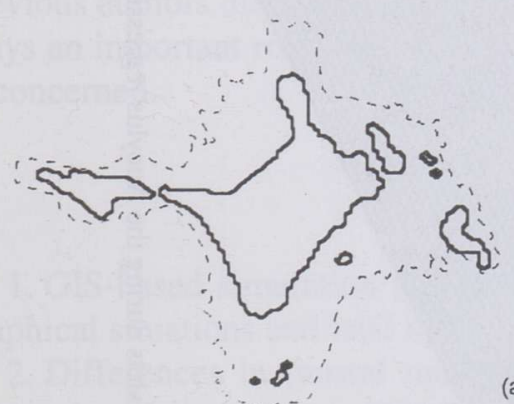

(a)

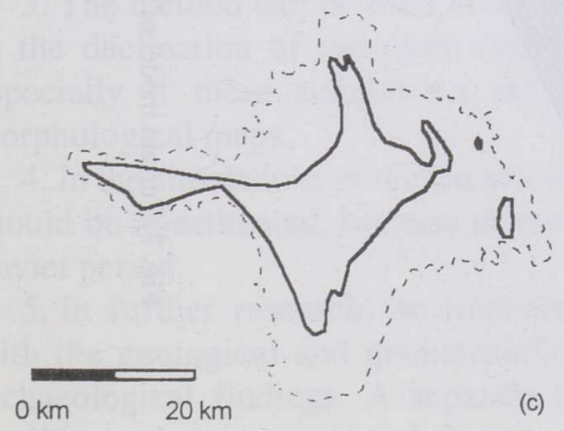

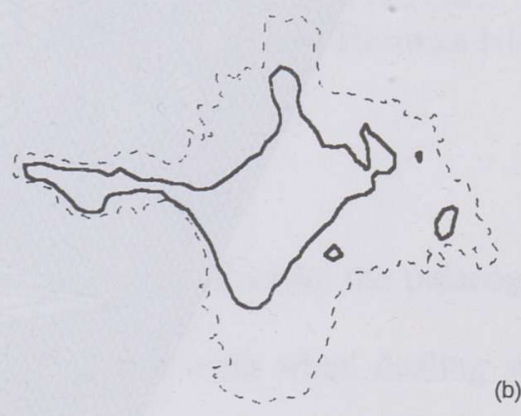

(b)

Fig. 6. The contours of the islets during the Ancylus regressive period (c. $8500 \mathrm{yr} \mathrm{BP}$ ). (a) Simulated with considering the differences in land uplift. (b) Simulated without counting differences in land uplift. (c) After Raukas \& Ratas, 1996. 


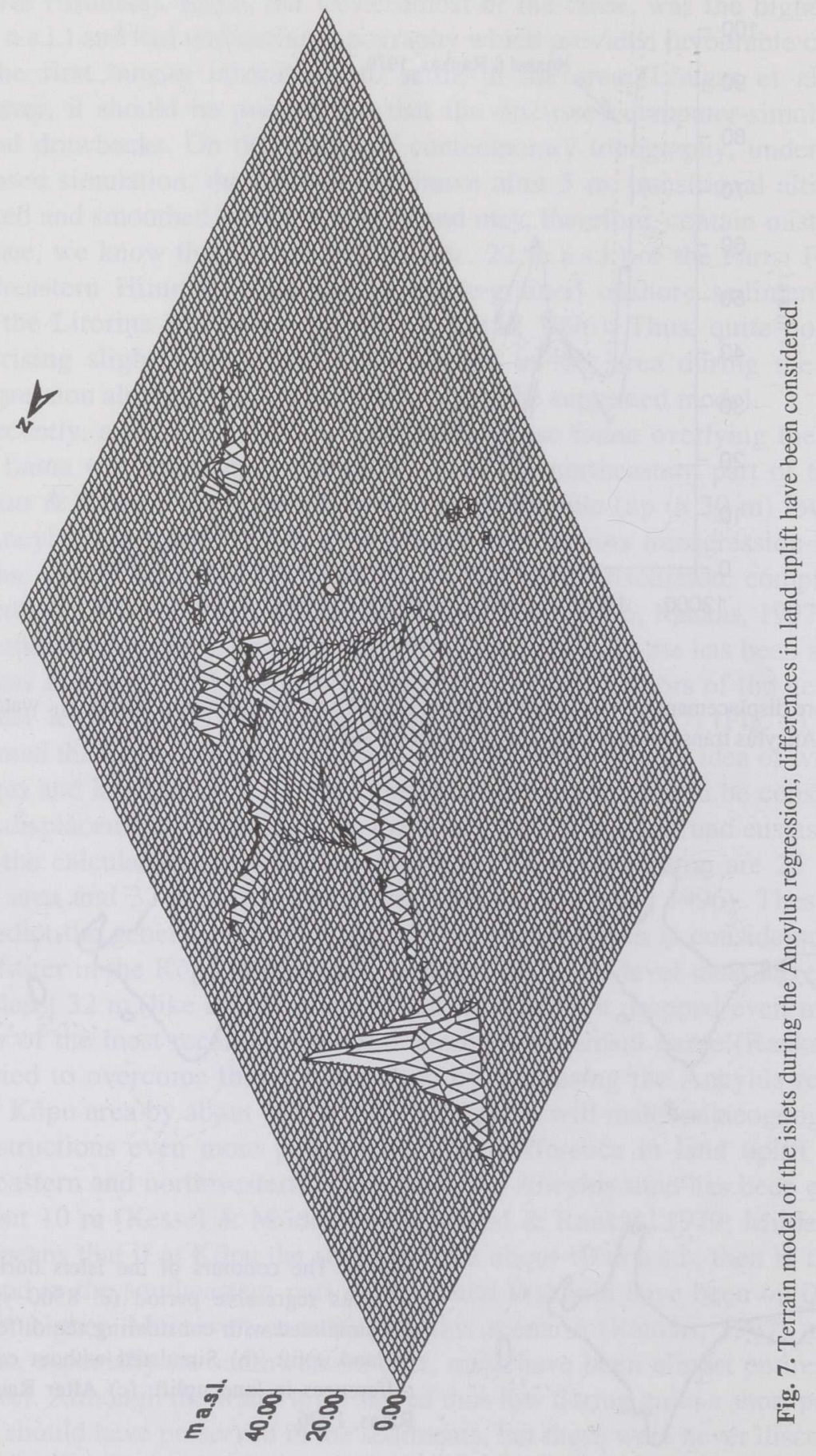


In the following, an attempt is made to simulate the contours of Hiiumaa Island for the discussed period of the Ancylus regression. Compared to the Ancylus transgression, the water level is assumed to have dropped by $30 \mathrm{~m}$ as recorded at Partsi (onshore sediments of the Litorina Sea at $11 \mathrm{~m}$ a.s.l.) (fig. 3 in Ratas \& Raukas, 1995). A mean value for the gradient of land uplift between the periods of the Ancylus transgression and the Litorina transgression has been calculated (Fig. 2). The configuration of the island during the Ancylus regression, as suggested by different methods used, shows notable differences (Fig. 6). It is remarkable that even if the differences in land uplift are taken into account, both the Kõpu area and the Partsi elevation constitute separate islands (Fig. 6a). The islets in the surroundings of Käina and Emmaste present in our model, but lacking on previous schemes, could be due to drawbacks of the methods used, which are not capable of excluding relief forms made up of younger sediments. For instance, we know that the topmost part of the Partsi Formation consists of the younger, Litorina Sea sediments; thus the computersimulated altitude (Fig. 7) of this area is probably wrong (as it counts also Litorina Sea sediments). The same concerns the central part of the main island (surroundings of Kapasto) and the easternmost part of the Kõpu Peninsula (remarkable eolian formations from the Litorina Stage) (Fig. 7). Therefore, only the contours of small islands are shown in Fig. 6a.

The computer-simulated contours of the islets, in which the differences in land uplift (Fig. 6b) were not taken into account, are similar to those obtained by Raukas \& Ratas (1996) (Fig. 6c). On this basis, it may be concluded that previous authors did not consider differences in land uplift and that the latter still plays an important role even when such a relatively small area as Hiiumaa Island is concerned.

\section{CONCLUSIONS}

1. GIS-based simulation is a promising tool in reconstructing the palaeogeographical situations and land uplift.

2. Differences in crustal movements are important even when dealing with relatively small areas, e.g. Hiiumaa Island.

3. The method can be used in checking the validity of the current opinions as to the declination of the more rapidly uplifting portions of the Earth's crust, especially if these simulations are compared with the geological and geomorphological maps.

4. In the simulations of the ancient shorelines in Estonia, previous investigations should be re-estimated, because of the deformations on the maps used during the Soviet period.

5. In further research, an important step is the comparison of the results with the geological and geomorphological maps, as well as with the maps of archaeological findings. A separate task is the correlation of the model with nonlinear relative water level changes. 


\title{
ACKNOWLEDGEMENTS
}

This study was supported by the Swedish Society of Anthropology and Geography (SSAG). Dr. Avo Miidel kindly read the manuscript and made valuable suggestions. The language was revised by Helle Kukk.

\section{REFERENCES}

De Geer, G. 1888. Om Skandinaviens nivåförändringar under Quartärperioden. Geol. Fören. Stockh. Förh., 10, 366-379.

Haila, H. \& Raukas, A. 1992. Ancylus Lake. In Geologiya Finskogo zaliva (Raukas, A. \& Hyvärinen, H., eds.), pp. 283-296. Estonian Academy of Sciences, Tallinn (in Russian).

Kents, P. 1939. Postglatsiaalsed Läänemere randjoone võnkumised Eestis illustreeritud Kõpu poolsaarel. Tartu. Manuscript in Estonian Academic Library.

Kessel, H. \& Miidel, A. 1973. On the Late- and Post-Glacial crustal movements in Estonia. ENSV TA Toim. Keem. Geol., 22, 3, 257-264.

Kessel, H. \& Raukas, A. 1967. Pribrezhnye otlozheniya Antsilovogo ozera i Litorinovogo morya $v$ Éstonii. Valgus, Tallinn (in Russian).

Kessel, H. \& Raukas, A. 1979. The Quaternary history of the Baltic. Estonia. In The Quaternary History of the Baltic (Gudelis, V. \& Königsson, L.-K., eds.). Acta Univ. Ups. Symp. Univ. Ups. Ann. Quing. Cel., 1, 127-146.

Lõugas, L., Kriiska, A. \& Moora, H. 1996. Coastal adaptation and marine exploitation of the Island of Hiiumaa, Estonia, during the Stone Age with special emphasis on the Kõpu I site. PACT, 50, 197-211.

Miidel, A. 1995. An attempt to apply trend-surface analysis to the study of raised shorelines of the Baltic Sea in Estonia. Proc. Estonian Acad. Sci. Geol., 44, 2, 97-110.

Ratas, U. \& Raukas, A. 1995. Hiiumaa Läänemere arengu etalonalana. In XVIII Estonian Naturalists Congress. The Nature of Hiiumaa (Kukk, T., ed.), pp. 8-11. Estonian Academy Publishers, Tartu-Tallinn.

Raukas, A. 1997. Evolution of the Baltic Sea. In Geology and Mineral Resources of Estonia (Raukas, A \& Teedumäe, A., eds.), pp. 268-273. Estonian Academy Publishers, Tallinn.

Raukas, A. \& Ratas, U. 1996. Holocene evolution and paleoenvironmental conditions of Hiiumaa island, northwestern Estonia. PACT, 50, 167-174.

Sepp, U. 1974. Hiiumaa maastikuline iseloomustus. Valgus, Tallinn.

\section{LÄÄNEMERE JÄÄAJAJÄRGSETE RANNAJOONTE REKONSTRUKTSIOON HIIUMAAL}

\author{
Tiit HANG ja Toomas KOKOVKIN
}

Geograafilise infosüsteemi abil on modelleeritud Hiiumaa jääajajärgset kerkimist Läänemerest. Metoodika väljatöötamiseks valiti kaks selgesti väljakujunenud rannajoontega transgressiivset faasi Läänemere arengus (Antsülusjärv ja Litoriinameri). Arvuti abil modelleeriti lineaarsed pinnad, mis väljendavad rannajoonte kõrguse muutusi mainitud ajalõikudest tänapäevani, ning need pinnad lahutati saare nüüdisreljeefi kujutavast digitaalsest mudelist. Tulemuseks 
on praegusest erineva rannajoone ja reljeefiga saared. Võrdlus varasemate, manuaalselt valminud mudelitega näitab mõningat lahknevust, mis on tingitud erinevatest aluskaartidest ja subjektiivsusest tektoonilise kerkimise arvestamisel.

Meetodit kasutati ka Antsülusjärve lõpus eksisteerinud vaidlusitekitava regressiivse perioodi Hiiumaa rannajoone modelleerimisel. Seejuures toetuti geoloogilistele andmetele Partsist ja varasemate uurijate poolt Antsülusjärve staadiumi iseloomustamisel kasutatud tektoonilise kerke erinevuse koefitsiendile.

Meetodit võib soovitada Läänemere varasemate staadiumide rannajoonte edaspidiseks uurimiseks, eriti seniste mudelite kiireks ja objektiivseks hindamiseks; samuti tektoonilise kerke koefitsiendi, kiirema kerke deklinatsiooni ja teiste näitajate muutumisel tekkivate stsenaariumide analüüsiks. Aluskaarti tuleb suhtuda kriitiliselt ja siduda sellest lähtuvate ebatäpsuste vältimiseks kogu Eesti rannajoonte andmebaas geograafiliste koordinaatidega. Arvuti modelleeritud reljeef ei ole täielikult usaldusväärne, sest selle aluseks on nüüdisreljeef koos nooremate pinnavormidega. Viimaste mudelist eemaldamiseks ilmselt napib geoloogilisi andmeid. Meetodi arendusena oleks vaja rannajoone mittelineaarsed muutused ühendada ajaskaalaga.

\section{РЕКОНСТРУКЦИЯ ПОСЛЕЛЕДНИКОВЫХ БЕРЕГОВЫХ ЛИНИЙ ОСТРОВА ХИЙУМАА В БАЛТИЙСКОМ МОРЕ, ЗАПАДНО-ЭСТОНСКИЙ АРХИПЕЛАГ}

\section{Тийт ХАНГ и Тоомас КОКОВКИН}

Использована географическая инфосистема для реконструкции береговой линии тектонически поднимающегося о-ва Хийумаа. С этой целью выбраны две трансгрессивные фазы развития Балтийского моря (Анциловое озеро и Литориновое море), когда береговые контуры острова отличались особой четкостью. Исходя в основном из геоморфологических данных смоделированы плоскости уровня моря в названные фазы, которые затем были вычтены из модели современной топографии острова. Следует отметить, что такая модель учитывает тектоническую деклинацию и ее интенсивность, улучшает топографические данные по сравнению с показателями, полученными вручную, а также уменьшает степень субъективности. Вместе с тем к достоверности выводов следует относиться критически, поскольку, во-первых, исходная карта изолиний с шагом 5 м не обеспечивает достаточной точности и, во-вторых, береговой рельеф содержит более поздние эоловые образования.

Эта же модель была применена для реконструкции спорной регрессии Балтийского моря в конце Анцилового периода. Дальнейшее ее развитие предполагает связывание изменений береговой линии с абсолютной шкалой времени. 